Biochimica et Biophysica Acta, 474 (1977) 180-187

(C) Elsevier/North-Holland Biomedical Press

BBA 98807

\title{
AGE-ASSOCIATED STRUCTURAL ALTERATIONS IN SENESCENT MOUSE BRAIN DNA
} CHRISTOPHER J. CHETSANGA, MELISSA TUTTLE, ANN JACOBONI and CRYSTAL
JOHNSON

Laboratory of Molecular Biology, Department of Natural Sciences, The University of Michigan-Dearborn, Dearborn, Mich. 48128 (U.S.A.)

(Received May 4th, 1976)

(Revised manuscript received September 7th, 1976)

\section{Summary}

The maintenance of structural integrity in the DNA of aging mice has been examined with the aim in view of determining whether changes in genome structure constitute the molecular basis of aging. Cell lysate DNA from brains of differently aged mice was subjected to alkaline sucrose gradient sedimentation. The results show that brain DNA from young mice sediments monodispersely while that from senescent mice exhibits polydisperse sedimentation patterns, banding in four peaks corresponding to number-average . molecular weights of $1.4 \cdot 10^{8}, 70 \cdot 10^{6}, 15 \cdot 10^{6}$ and $3 \cdot 10^{6}$.

When treated with nuclease $S_{1}$, it was the 30 month mouse DNA whose sedimentation shifted to the top of the gradient indicating a reduction in its molecular weight as a result of nuclease digestion. The apparent increase in single strand breaks implies that the rate of breakage in old mouse brain DNA is faster than that of repair replication. The conclusion is drawn that senescence could result from an accumulation of defects in the genome.

\section{Introduction}

After an organism reaches middle age, there always ensues an eventual breakdown in the homeostatic equilibrium of its metabolic processes ultimately resulting in death [1]. Various theories have been put forward to explain the basis for this breakdown in metabolic homeostasis that occurs in old age [2]. Strehler et al. [3] have proposed a hypothesis whereby the codon system eventually becomes restricted as senescence progresses. The finite doubling times observed for cultured animal cells in vitro [4] suggests the existence of a developmental program that regulates the timing of cellular senescence.

If the process of aging is under the control of a genetic program, it is reason. 
able to expect that a disruption of the genetic program would result in a homeostatic dis-equilibrium. The disruption of the program could result in somatic cell mutation [5]. We have recently shown that the liver DNA of old mice accumulates single-stranded discontinuities [6]. These results provided experimental evidence to indicate that the development of genetic instability is associated with senescence. The presence of single-strand defects in the genome can be studied under denaturing conditions whereby the DNA becomes dissociated into a number of single-stranded fragments whose quantities and sizes can be measured. In the studies presented in this paper we have used denaturing sedimentation conditions to demonstrate the presence of single-strand breaks in the DNA of post-mitotic brain cells of old mice.

\section{Materials and Methods}

Procurement of tissues. The $\mathrm{CBF}_{1}$ mice used in the experiments reported in this paper were obtained from Charles River Breeding Laboratories. The mean life-span of these mice is 30 months. The mice were decapitated, then the brains quickly frozen in $0.12 \mathrm{M}$ sodium borate buffer, $\mathrm{pH} 8.5$, and stored at $-40^{\circ} \mathrm{C}$. In some cases the tissues were collected in chilled borate buffer and used immediately for DNA purification or cell lysate preparation.

Preparation of cell suspensions. This procedure was carried out at $1-4^{\circ} \mathrm{C}$. In a typical experiment brains from three mice were minced to fine pieces with a pair of scissors and rinsed with three changes of $50 \mathrm{ml}$ of chilled borate buffer $(0.18 \mathrm{M} \mathrm{NaCl}, 0.02 \mathrm{M}$ disodium EDTA, $0.12 \mathrm{M}$ boric acid, and $0.042 \mathrm{M}$ $\mathrm{NaOH}$ ), $\mathrm{pH}$ 8.5. After homogenization with a loose-fitting all-glass homogenizer, the suspension was filtered through four layers of cheese-cloth and centrifuged at $3000 \mathrm{rev} . / \mathrm{min}$ for $5 \mathrm{~min}$. The pellet was washed two more times by resuspension in 10 volumes of $\mathrm{SSC}(\mathrm{SSC}=0.15 \mathrm{M} \mathrm{NaCl}, 0.015 \mathrm{M}$ sodium citrate, $\mathrm{pH}$ 7.0) and centrifuging at $5000 \mathrm{rev} . / \mathrm{min}$ for $10 \mathrm{~min}$ each time. Cell number was estimated by using a microscope. The pellets were defatted by sequentially washing with $25 \mathrm{ml}$ of $95 \%$ ethanol, $25 \mathrm{ml}$ of diethyl ether, and finally $25 \mathrm{ml}$ of $95 \%$ ethanol accompanied by centrifuging at $8000 \mathrm{rev} . / \mathrm{min}$ for $10 \mathrm{~min}$ each time. The pellet was finally washed with 20 volumes of borate buffer to remove any remaining ethanol and used for preparing DNA or cell lysates.

$D N A$ preparation. We experienced considerable problems in achieving satisfactory recoveries of brain DNA by conventional methods $[7,8]$. The procedure with which we had greater success is described below. The defatted cell pellet was processed by the method of Klotz and Zimm [9] to lyse the cells for DNA purification. This involved thoroughly suspending the pellet in $10 \mathrm{ml}$ of boric acid buffer ( $\mathrm{pH} \mathrm{8.5)}$. To this suspension was added $0.2 \mathrm{ml}$ of $25 \%$ brij 58 (Calbiochem), $0.2 \mathrm{ml}$ of $25 \%$ sarkosyll ( $\mathrm{K}$ and $\mathrm{K}$ Fine Chemicals) and $5 \mathrm{mg}$ of nuclease-free pronase (Calbiochem). The viscous DNA slurry was incubated at $68^{\circ} \mathrm{C}$ for $20 \mathrm{~min}$ with gentle mixing in a shaker water bath. It is important that the preparation be homogeneously suspended before the incubation. The suspension was treated with $2.5 \mathrm{mg}$ of more pronase and incubated for $4 \mathrm{~h}$ at $50^{\circ} \mathrm{C}$.

The suspension was now extracted with a chloroform/isoamyl alcohol/ 
phenol mixture (24:1:25, v/v) by shaking for $20 \mathrm{~min}$ at room temperature and centrifuging at $10000 \mathrm{rev} . / \mathrm{min}$ for $10 \mathrm{~min}$. The aqueous phase was collected and re-extracted with chloroform/isoamyl alcohol/phenol mixture repeatedly until the interphase was clear. DNA was precipitated with an equal volume of chilled 95\% ethanol. The spooled DNA was dissolved in $2 \mathrm{ml}$ of SSC and treated with $40 \mu \mathrm{g}$ of pre-heated ribonuclease (RNAase) for $30 \mathrm{~min}$ at $37^{\circ} \mathrm{C}$. The DNA solution was made $0.3 \mathrm{M} \mathrm{in} \mathrm{NaCl}$ and $0.5 \%$ in sarkosyll and extracted with chloroform/isoamyl alcohol/phenol mixture until the interphase was clear. The DNA was precipitated with ethanol, dissolved in $0.1 \times$ SSC and dialyzed against the same solution. About $70 \%$ of the DNA was recovered at this stage. Alternatively, after RNAase treatment, the DNA was mixed with solid $\mathrm{CsCl}$ to a final density of about $1.710 \mathrm{~g} / \mathrm{cm}^{3}$ and centrifuged for $60 \mathrm{~h}$ at $30000 \mathrm{rev}$./ min (rotor SW 50) at $20^{\circ} \mathrm{C}$. After collecting fractions from the $\mathrm{CsCl}$ gradients and measuring the $A_{260 \mathrm{~nm}}$, the DNA-containing fractions were pooled and dialyzed against several changes of $0.1 \times$ SSC. DNA concentration was determined spectrophotometrically by using the relationship $1 A_{260 \mathrm{~nm}}=50 \mu \mathrm{g}$ DNA per $\mathrm{ml}$. The $\mathrm{CsCl}$ gradient method of final purification after RNAase treatment achieved about 90\% recovery of DNA while extraction with chloroform/ isoamyl alcohol/phenol mixture gave about $65 \%$ recovery of the DNA subjected to this final stage of purification.

Alkaline sucrose gradients. The sedimentation behavior of DNA was analyzed in $5-20 \%$ sucrose gradients made in $0.01 \mathrm{M}$ EDTA, $0.4 \mathrm{M} \mathrm{NaCl}$ and $0.5 \mathrm{M}$ $\mathrm{NaOH}$ (alkaline saline/EDTA) [10]. About $15 \mu \mathrm{g}$ of purified DNA or cell lysate DNA (from approx. $3 \cdot 10^{6}$ cells) were incubated in $0.5 \mathrm{ml}$ of alkaline saline/ EDTA for 20 min at $22^{\circ} \mathrm{C}$, carefully loaded on top of a $38 \mathrm{ml}$ sucrose gradient and centrifuged at $10500 \mathrm{rev} . / \mathrm{min}$ (rotor SW 27) for $18 \mathrm{~h}$ at $4^{\circ} \mathrm{C}$ [11]. The bottoms of the nitrocellulose tubes were punctured, 1.8-mi fractions collected and processed by the method of Siegel et al. [12]. In mixing experiments, cell lysates were made from equal numbers of cells from 6 - and 30 -month mouse brains and then analyzed on sucrose gradients.

Gradients were calibrated using $\mathrm{T}_{4}$ phage DNA. About $0.5 \mu \mathrm{g}$ of $\left[{ }^{3} \mathrm{H}\right]$ thymidine-labelled mouse L1210 cell lysate DNA $\left(10^{5}\right.$ cells $)$ was included in some gradients for comparison. The sedimentation coefficients based on the peaks of mouse DNA were determined relative to that of $T_{4}$ phage-denatured DNA $(57.5 \mathrm{~S})$ [13]. After sedimentation analysis [14] the calibrated $s_{20}$ was used to compute the molecular weight $(M)$ by the equation of Studier [15], assuming $\alpha=0.4$.

The method of Ehmann and Lett [16] was used to calculate the numberaverage molecular weight $\left(M_{\mathrm{n}}\right)$ and the weight-average molecular weight $\left(M_{\mathrm{w}}\right)$ over the regions of the gradients encompassing the peaks. The ratio $M_{\mathrm{w}} / M_{\mathrm{n}}$ was used to estimate the randomness of the distribution of the DNA molecules of different sizes. The $M_{\mathrm{n}}$ of 6 month brain DNA $\left(M_{\mathrm{n}, 6}\right)$ and that of each peakregion of 30 month brain DNA $\left(M_{n, 30}\right)$ were used to derive estimates of the number of single-strand breaks in the DNA of old mouse brain.

Nuclease $S_{1}$ digestion of DNA. Nuclease $S_{1}$ was prepared by the method of Sutton [17] and used in determining the presence of single-stranded regions in brain DNA as described elsewhere [6]. The nuclease $S_{1}$ preparations used in these studies showed no activity towards double-stranded DNA. Some DNA 
samples (15 $\mu \mathrm{g}$ each) were first treated with nuclease $S_{1}$ and then resolved on alkaline sucrose gradients.

\section{Results}

\section{Sucrose gradients of cell lysates}

The sedimentation profiles in Fig. 1 show that the bulk of 6 month brain DNA sedimented either below or above $\mathrm{T}_{4}$ DNA $\left(1.2 \cdot 10^{8}\right.$ daltons $)$ while some cosedimented with it. It is assumed that the brain DNA sedimenting below $\mathrm{T}_{4}$ phage DNA had a molecular weight greater than $1.2 \cdot 10^{8}$. Starting from the heavier region of the gradient (Fig. 1), the DNA from 20 and 30 month brain is each distributed into four peaks with peak 1 containing the fastest sedimenting fraction of DNA. Each peak of 20 month brain DNA sediments to the heavier side of what seems to be a corresponding peak of 30 month brain DNA. For 20 month DNA, peak 2 contains the largest amount (40\%) of DNA, while peak 4 contains the largest amount (35\%) of 30 month brain DNA. Our calculations show that peak 1 contains $16 \%\left(1.4 \cdot 10^{8}\right.$ daltons $)$, peak $2,27 \%\left(70 \cdot 10^{6}\right.$ daltons), peak $3,23 \%\left(15 \cdot 10^{6}\right.$ daltons) and peak $4,34 \%$ (approx. $2 \cdot 10^{6}-5$ - $10^{6}$ daltons) of the total 30 month brain DNA loaded on the gradient.

The use of post-mitotic brain cell unlabelled DNA in the sedimentation runs made it necessary for us to use larger amounts of DNA than those used with labelled DNA [18]. The reproducibility of the results in Fig. 1 suggests, albeit inconclusively, that the $15 \mu \mathrm{g}$ of DNA resolved in each $38 \mathrm{ml}$ gradient did not sediment artifactually. Furthermore, $0.5 \mu \mathrm{g}$ of mouse L1210 cell [ $\left.{ }^{3} \mathrm{H}\right] \mathrm{DNA}$ sedimented to the same position in the gradient as the $15 \mu \mathrm{g}$ of the 6 month brain DNA in Fig. 1. Wheeler and Lett [19] resolved unlabelled DNA from the cerebella of differently aged beagles on sucrose gradients and also observed a breakdown in the DNA of old beagles.

Within the limits of resolution achieved under our experimental conditions, it appears that the pieces of 30 month brain DNA in peaks 2, 3, and 4 (Fig. 1)

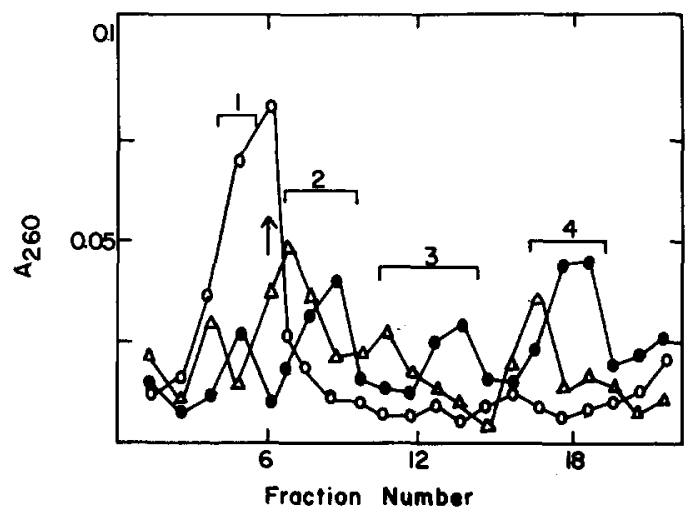

Fig. 1. Alkaline sucrose gradients of brain cell lysate DNA from 6-, 20- and 30-month-old mice. Direction of sedimentation is from right to left. Arrow indicates position of $\mathrm{T}_{4}$ phage DNA. Data based on three experiments. $\circ-0,6$ month brain; $\triangle \longrightarrow-\Delta, 20$ month brain; $\bullet-\bullet, 30$ month brain. Corresponding peaks of 20 and 30 month brain DNA are numbered together. 
result from 2, 9, and 46 single-strand breaks, respectively, in the DNA of the maximum size obtainable under our experimental conditions (Table I). The fact that the $M_{\mathrm{w}} / M_{\mathrm{n}}$ ratios in the DNA fractions are less than the expected value of 2 for randomly distributed molecules [16], and that four separate DNA peaks are observed in old cells (Fig. 1) suggests that the single-strand breaks are produced at discrete points.

The argument can be made that the 30 month brain DNA sedimented polydispersely in alkaline sucrose gradients because nucleases (peculiar to senescent brain cells) may have digested it during the extraction procedures. The possibility of the degradation of our DNA by nucleases was examined by performing two mixing experiments. In one experiment we mixed equal numbers of cells from 6- and 30-month brains, lysed them and resolved the DNA on alkaline sucrose gradients; in the other experiment a mixture of $\left[{ }^{3} \mathrm{H}\right]$ thymidine-labelled L12010 cells and 30-month brain cells was lysed and resolved on sucrose gradients. The results of these two experiments are presented in Fig. 2 where it can be observed that both 6 month brain DNA and L1210 $\left[{ }^{3} \mathrm{H}\right] \mathrm{DNA}$ continue to sediment in the same position in the heavy region of the gradient as in Fig. 1. It will be observed that the DNA from the lysates of the mixture of 6- and 30month brain cells sediments in four peaks; the shape and position of the first peak resemble that of 6 month brain DNA (Fig. 1). As we were monitoring DNA distribution by $A_{260} \mathrm{~nm}$, we could not resolve the first peak of 30 month brain DNA which bands in the same position as 6 month brain and L1210 cell DNA; the sizes and shapes of peaks 2,3 and 4 of 30 month brain DNA show no evidence of the contribution of digested DNA from another source other than 30 month brain DNA. From our calculations, it is clear that the size of peak 1 is consistent with the amount of 6-month brain cell lysates used in the gradients plus a small contribution from 30-month brain cell lysates. It is therefore apparent that 6 month brain DNA was not degraded by nucleases from 30 month brain cells during the extraction procedure. Furthermore, these results indicate that the four peaks obtained with 30 month brain DNA are not a result of the degradation of the DNA by nucleases during processing.

Nuclease $S_{1}$ digestion of $D N A$

For determining the presence of single-stranded regions in brain DNA, nu-

TABLE I

MOLECULAR WEIGHT DISTRIBUTIONS AND NUMBER OF SINGLE-STRAND BREAKS

Calculations based on data from Fig. 1.

\begin{tabular}{cccc}
\hline $\begin{array}{l}\text { Mouse age } \\
\text { (months) }\end{array}$ & $\begin{array}{l}\text { Percent } \\
\text { of DNA }\end{array}$ & $M_{\mathrm{w}} / M_{\mathrm{n}}$ & $\begin{array}{l}\text { Single-strand breaks } \\
\left(M_{\mathrm{n}, 6} / M_{\mathrm{n}, 30}\right)\end{array}$ \\
\hline $\begin{array}{c}\text { months } \\
\text { (Peak 1) }\end{array}$ & 100 & 1.14 & - \\
30 months & & & \\
Peak 1 & 16 & 1.02 & - \\
Peak 2 & 27 & 1.04 & 2 \\
Peak 3 & 23 & 1.35 & 9 \\
Peak 4 & 34 & 1.34 & 46 \\
\hline
\end{tabular}



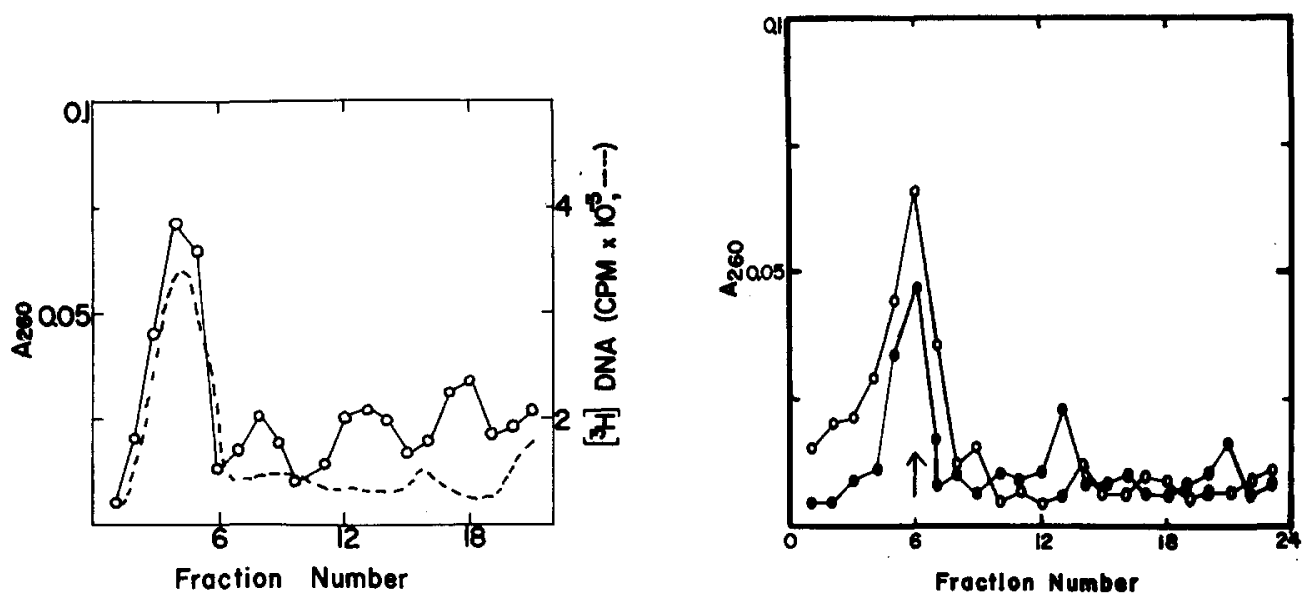

Fig. 2. Alkaline sucxose gradients of lysates of mixed mouse cells. Cells trom 6 month brain cells or L1210 cells were mixed with equal numbers of cells from 30-month brains and their DNA resolved on sucrose gradients. $O-O_{-}$, DNA from lysates of a mixture of 6 - and 30 -month brain cells; $\ldots . . .-$, mixture of $\left[{ }^{3} \mathrm{H}\right]$ thymidine-labelled $\mathrm{L} 12010$ cells and 30-month brain cells. Arrow indicates position of $\mathrm{T}_{4}$ phage DNA. Data based on two experiments.

Fig. 3. Alkaline sucrose gradients of 6 month mouse brain DNA. Digested DNA was treated with $15 \mu \mathrm{g}$ nuclease $S_{1}$. Arrow, $T_{4}$ phage DNA. Data based on two experiments. DNA treated with nuclease $S_{1}$ $(\bullet-\bullet)$; untreated DNA $(0-0)$.

clease $S_{1}$ prepared by the method of Sutton [17] was used as described elsewhere [6]. Table II shows the levels of nuclease digestion of brain DNA from differently aged mice. It can be observed that the sensitivity of native DNA to nuclease attack begins with 20 month brain DNA and reaches a maximum of $14.2 \%$ in 30 month brain DNA. About $95 \%$ of denatured DNA from the age groups studied was digested by the enzyme.

The existence of single-stranded gaps in old brain DNA was further analyzed by resolving 6 and 30 month brain DNA on alkaline sucrose gradients after treating the DNA with nuclease $S_{1}$. Fig. 3 shows that both nuclease-treated and untreated 6-month brain DNA samples sediment in one peak in the heavy region of the gradients. There was a very small amount of nuclease-treated DNA that banded in the lighter portion of the gradient. Fig. 4 reveals a much higher level of digestion of 30 month brain DNA by nuclease $S_{1}$. About $35 \%$ of the

\section{TABLE II}

DIGESTION OF MOUSE BRAIN DNA BY NUCLEASE $s_{1}$

pata based on four experiments.

\begin{tabular}{llr}
\hline Mouse age & \multicolumn{2}{l}{ DNA digested (\%) } \\
\cline { 2 - 3 } & Denatured & \multicolumn{1}{l}{ Native } \\
\hline 6 & 96 & $2.2 \pm 0.3$ \\
15 & 95 & $2.0 \pm 0.6$ \\
20 & 95 & $10.4 \pm 0.7$ \\
30 & 96 & $14.2 \pm 1.1$ \\
\hline
\end{tabular}




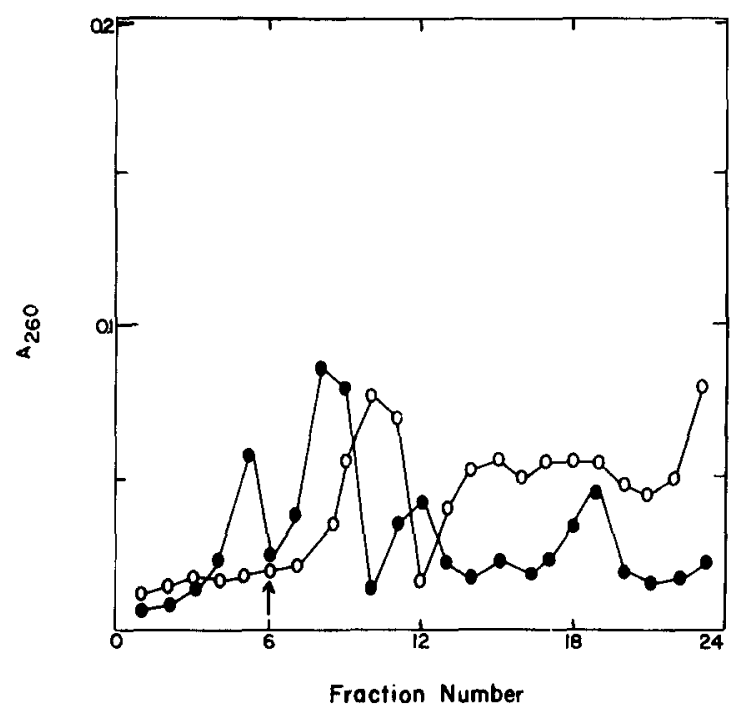

Fig. 4. Alkaline sucrose gradients of digested and undigested 30 month mouse brain DNA. Digested DNA was treated with $15 \mu$ nuclease $S_{1}$. Arrow, $T_{4}$ phage DNA. Data based on three experiments. Nuclease

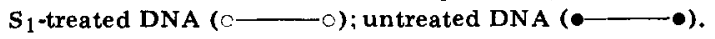

DNA now bands in a broadbased peak towards the bottom of the gradient, while $65 \%$ of the DNA sediments polydispersely in the region from fraction 12 to the top of the gradient.

\section{Discussion}

The procedure used for cell lysis [9] works best when cell suspensions devoid of connective tissue are used. The defatting steps help in ensuring an even suspension of cells lysates in the lysing medium. Klotz and Zimm [9] found no evidence of digestion of DNA by nucleases under these lysis conditions.

The observed polydispersity of old mouse DNA indicates the existence of either single-stranded discontinuities or nicks in the DNA. When such DNA is sedimented under denaturing conditions the constituent single strands will sediment in different regions of the gradient as is observed in Fig. 1. This polydisperse banding of DNA from senescent mice was accentuated by prior treatment of the DNA with nuclease $S_{1}$ before centrifugation (Fig. 4).

Although it is not possible to rule out limited degradation of the DNA during extraction as an explanation for the sedimentation profiles that we obtained with old mouse DNA, we have found no evidence of digestion of DNA by nucleases under our lysis conditions. We feel therefore that our results probably reflect the true state of 30 month brain DNA in vivo.

The decrease in molecular weight of rat liver DNA with advancing animal age observed by Massie et al. [20] is thus supported by our results with mouse brain DNA. Our results also support those of Price et al. [21] who used autoradiography to demonstrate that calf thymus DNA polymerase catalyzes a greater incorporation of $\left[{ }^{3} \mathrm{H}\right] \mathrm{dATP}$ into nuclei of old mouse neurons, an ob- 
servation consistent with an accumulation of single-stranded gaps in the DNA of old neurons.

The present results corroborate our earlier observation on the accumulation of single-stranded regions in liver DNA of senescent mice [6]. These observations are consistent with the notion that aging results from defects in an organism's genome with the net result that crucial gene functions become defective. In addition to genetic instability resulting from replication errors [22] in the case of mitotic cells, breaks in certain genes may result in transcription errors that could lead either to incomplete RNA chains or to non-sense codons.

\section{Acknowledgements}

This work was supported in part by Institutional Research Grant No. IN 40 40-0 to the University of Michigan from the American Cancer Society and grant No. 340879 from the Michigan Heart Association. The mice used in this study were provided by the National Institute on Aging (N.I.H.).

\section{References}

1 Comfort, A. (1968) Gerontologia 14, 224-234

2 Hay flick, L. (1975) Fed. Proc. 34, 9-13

3 Strehler, B., Hirsch, G., Gusseck, D., Johnson, R. and Bick, M. (1971) J. Theor. Biol. 33, $429-474$

4 Hay flick, L. (1965) Exp. Cell. Res, 37, 614-636

5 Curtis, H.J. (1963) Science 141, 686-694

6 Chetsanga, C.J., Boyd, V., Peterson, L. and Rushlow, K. (1975) Nature 253, 130-131

7 Marmur, J. (1961) J. Mol. Biol. 3, 208-218

8 Church, R.B. and McCarthy, B.J. (1968) Biochem. Genet. 2, 55-73

9 Klotz, L.C. and Zimm, B.H. (1972) J. Mol. Biol. 72, 779-800

10 Olive, P.L. and McCalla, D.R. (1975) Cancer Res. 35, 781-784

11 Kohn, K.W., Friedman, C.A., Ewig, R.A.G. and Iqbal, Z.M. (1974) Biochemistry 13, 4134-4139

12 Siegel, S.E., Patch, C.T., Lewis, Jr., A.M. and Levine, A.S. (1975) J. Virol. 16, 43-52

13 Rubenstein, I. and Leighton, S.B. (1974) Biophys. Chem. 1, 292-299

14 Peterson, A.R., Bertram, J.S. and Heidelberger, C. (1974) Cancer Res. 34, 1592-1599

15 Studier, F.W. (1965) J. Mol. Biol. 11, 373-390

16 Ehmann, U.K, and Lett, J.T. (1973) Radiat. Res. 54, 154-162

17 Sutton, W.D. (1971) Biochim. Biophys. Acta 240, 522-531

18 McBurney, M.W., Graham, F.L. and Whitmore, G.F. (1972) Biophys. J. 12, 369-383

19 Wheeler, K.T. and Lett, J.L. (1974) Proc. Natl. Acad. Sci. U.S. 71, 1862-1865

20 Massie, H.R., Baird, M.B., Nicolosi, R.J. and Samis, H.B. (1972) Arch. Biochem. Biophys. 153, 736741

21 Price, G.B., Modak, S.P. and Makonodan, T. (1971) Science 171, 917-920

22 Loeb, L.A., Clark, C.F. and Battula, N. (1974) Cancer Res. 34, 2311-2321 